\title{
Effect of gel formulation obtained from Fomes fomentarius on bleeding and clotting time: A pilot study
}

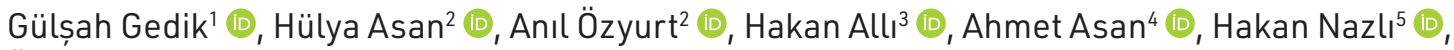 \\ Önder Sarp 5 (D) \\ 'Trakya University, Faculty of Pharmacy, Department of Pharmaceutical Technology, Edirne, Turkey \\ ${ }^{2}$ Trakya University, Faculty of Dentistry, Edirne, Turkey \\ ${ }^{3}$ Mugla Sitki Kocman University, Faculty of Arts and Science, Department of Biology, Mugla, Turkey \\ ${ }^{4}$ Trakya University, Faculty of Science, Department of Biology, Edirne, Turkey, \\ ${ }^{5}$ Trakya University, Faculty of Pharmacy, Department of Pharmaceutical Technology, Edirne, Turkey
}

ORCID IDs of the authors: G.G. 0000-0003-4147-6729; H.A. 0000-0002-9650-9498; A.0̈. 0000-0002-3243-3156;

H.A. 0000-0002-1238-3227; A.A. 0000-0002-4132-3848; H.N. 0000-0001-5763-1450; 0̈.S. 0000-0003-1127-9273

Cite this article as: Gedik, G., Asan, H., Ozyurt, A., Alli, H., Asan, M., Nazli, H., \& Sarp, O. (2020). Effect of gel formulation obtained from Fomes fomentarius on bleeding and clotting time: A pilot study. Istanbul Journal of Pharmacy, 50 (3), 216-223.

\begin{abstract}
Background and Aims: Fomes fomentarius (L.) Fr. (jar fungus) has been used extensively in the past by surgeons, barbers, dentists, and is therefore called surgeon's fungus. The hemostatic properties of $F$. fomentarius extracts are important in medicine. The aim of this study was to investigate the effect of the gel formulation obtained from Fomes Fomentarius on bleeding and clotting time in rat models.

Methods: The gel was made for this purpose and a cross-linked polymer of acrylic acid was used as a gelling agent.

Results: The outcomes of the characterization analysis indicate the development of a successful gel formulation with optimum characteristics. Data from the antimicrobial study showed a good inhibition zone, with the strongest values against Klebsiella pneumoniae, Candida krusei, C. tropicalis, C. guilliermondii. The gel administration shortened the hemostasis time after bleeding from skin incisions by $63.9 \%$ and tail incisions by $55.63 \%$ from the original time. For coagulation time, these results are determined as $71.56 \%$ from the original time. The gel administration shortened the coagulation time after bleeding from the tail incisions by $69.9 \%$ from the original time.

Conclusion: Our preliminary study showed that the gel formulation obtained from F. fomentarius is a potent hemostatic agent in a rat-bleeding model.
\end{abstract}

Keywords: Fomes fomentarius, bleeding time, coagulation time

\section{INTRODUCTION}

F. fomentarius, beech tree (Fagus sylvatica L.) and other deciduous species are developing as parasites or saprophytes, large wide variety of woody, perennial fungus with various sizes (Vetrovsky, Vorísková, \& Snajdr, 2011). F. fomentarius is a white root fungus. Fruit body of between 5 and $50 \mathrm{~cm}$ across, 3 and $25 \mathrm{~cm}$ wide and 2 and $25 \mathrm{~cm}$ thick, which attaches broadly to the tree on which the fungus is growing. While typically shaped like a horse's hoof, it can also be more bracket-like with an umbonate attachment to the substrate. The species typically has broad, concentric ridges, with a blunt and rounded margin. The flesh is hard and fibrous, and a cinnamon brown colour. The pores are circular, and there are 2-3 per millimeter. Odor pleasantly fungoid, taste rather bitter. 
A saprophyte or weak parasite on Fagus (beech), also on other hardwoods and rarely on conifers (Pacioni, 1985; Ellis \& Ellis, 1990). Spores is oblong-ellipsoid, smooth, hyaline, 18-19x5-6 $\mu$. It is known as "kav mantarı" in Turkey. The inside was a fungus used to light fire (Allı, Işıloğlu, \& Solak, 2007).

F. fomentarius has been used extensively in the past by surgeons, barbers and dentists, and is therefore called surgeon's fungus. People used it as a medicine in Germany. In addition, F. fomentarius extract has been used in Europe, West Siberia and Indian folk medicine for dressing with iodine for external wounds and burns. Mushrooms are called "Wundschwamm" or "Chirurgenschwamm" in the alpine region of Switzerland. This preparation was sold in pharmacies in bandage form as an anti-bleeding agent and was used by Austrian farmers until the $19^{\text {th }}$ century. Fomitin, the active ingredient of the $F$. fomentarius, is also used against dysmenorrhea, hemorrhoids and bladder diseases. There is information about the use of $F$. fomentarius for esophagus, stomach and uterine cancer in the literature (Grienke, Zöll, \& Peintner, 2014). Also F. fomentarius has been used in traditional Chinese medicine for the treatment of oral ulcers, gastroenteritis, inflammations and various cancers (Chen, Zhao, \& Li, 2011). In some studies, F. fomentarius has been reported to have hypoglycemic, anti-nociceptive, anti-inflammatory, anti-infective and anti-tumor activities (Seniuk et al., 2011; Park et al., 2004). A study demonstrated that F. fomentarius ethanol extract inhibits cell motility and growth and induces apoptosis by inhibiting the phosphoinositide 3kinase /AKT pathway and caspase activation (Seon-Ok, MinHo, \& Kyung-Ran, 2019).

Several classes of metabolites were identified: Primary metabolites polysaccharides (glucans), polysaccharide-protein complexes, and secondary metabolites such as triterpene glycosides, esters and lactones (fungisterollinoleate, betulin 28-Oacetate), alcohols (7 ergostenol, sitosterol), aldehydes and ketones (protocatechualdehyde), organic acids, benzofurans (paulownin), coumarins (daphnetin), and volatile components (Grienke et al., 2014). The most important compounds with clinically beneficial activity are glucans. In vitro studies have suggested that large molecular weight or particular glucans can directly activate leukocytes, stimulating their phagocytic, cytotoxic and antimicrobial activities, including the production of reactive oxygen and nitrogen intermediates (Akramiene, Kondrotas, \& Didziapetriene, 2007). The presence of polysaccharides in the polar extracts was considered to be very important because a previous study had shown that a water-soluble melanin-glucan complex (containing 80\% melanins and 20 $\% \beta$-glucans) completely inhibited the growth of C. albicans (Seniuk et al., 2011). The antifungal activities of $F$. fomentarius against Aspergillus flavus, A. fumigatus, Absidia orchidis and Candida krusei were shown in a study (Dresh et al., 2015).Hemorrhagic properties of $F$. fomentarius extracts are important in medicine and dentistry. This feature of F. fomentarius, we wanted to make human life safe by using these extracts to save lives of patients in traffic accidents, injuries, allergies and respiratory diseases, genetic disorders, hemophilia and bleeding and clotting disorders and to improve the quality of life.
The characteristics of an ideal topical hemostat should include various properties such as, stopping arterial and venous bleeding in 2 minutes, no need special storage conditions, durable and light insensitive, long shelf live ( $>2$ years), no need special training for its use, easy to use in difficult whether and war conditions, easy to be self applicable, effective on complex, tourniqetless and hypothermic wounds, effective in patients using antiaggregants or anticoagulants, do not delay would healing, easily cleaned and bioabsorbed from the application area and provide an antimicrobial envirement, no local or systemic side effects and cost effective (Kheirabadi, 2011; Pusateri et al., 2003).

Some hemostat agents types, mechanism of action, studies and disadvantages are given in Table1. Although very important studies have been carried out over the last years, a product with all the characteristics of the ideal topical hemostat, even with clinical trials and animal experiments, has not yet been developed. Our study was planned to demonstrate the bleeding-inhibiting properties of F. fomentarius.

\section{MATERIALS AND METHODS}

\section{Reagents and chemicals}

Carbomer 940 powder (Lubrizol) and Triethanolamine (SigmaAldrich) was chosen for the gel formulation. Double-distilled water was used throughout the study.

\section{Mushroom material}

The aerial parts (fruit bodies) of F. fomentarius were collected by Hakan Allı on March 25, 2014, on Liquidambar orientalis Mill. in Köycegiz in the Toparlar region of Mugla, Turkey. A sample of the fungus was authenticated and a voucher specimen (No: 5379) was deposited in the herbarium of the Mugla University Faculty of Sciences. The fungus parts were ground to a powder using a porcelain mortar and pestle.

\section{Preparation of gel formulation}

The aqueous extract for formulation was obtained via extraction of $5 \mathrm{~g}$ fungus powder with $100 \mathrm{~mL}$ distilled water at $80^{\circ} \mathrm{C}$ for 30 min using a water bath (Daihan Scientific, WB-22, Korea). The extract was filtered through Grade 1 Whatman paper. Carbomer 940 powder (2\%) was added to the filtrate. Triethanolamine was then added and mixed with it enough to gel. The formulation was kept at $25 \pm 1^{\circ} \mathrm{C}$ for 48 hours to see a possible phase separation.

\section{Characterization of gel formulation}

Gel was evaluated as for its clarity, $\mathrm{pH}$ and viscosity. The experiments were repeated four times.

\section{Clarity of formulation}

The clarity of gels was determined by optical check under dark color background, and it was scaled as follows: turbid, +; clear, ++; and very clear, +++ (Okur, Yoltaş, \&Yozgatli, 2016).

\section{Measurement of $\mathbf{p H}$}

The $\mathrm{pH}$ of the formulation was detected by a digital $\mathrm{pH}$-meter (Mettler Toledo S 220, Switzerland). Measurements were performed four times and an average of these measurements was accepted as the $\mathrm{pH}$ of the in-situ gels. 
Table 1. Type, content, brand name, mechanism of action, studies and disadvantages of some hemostatic agents.

\begin{tabular}{|c|c|c|c|c|}
\hline Type & Content & $\begin{array}{c}\text { Brand } \\
\text { Name(s) }\end{array}$ & Mechanism of Action & $\begin{array}{l}\text { Studies and Disadvantages: } \\
\text { Drawbacks of Materials }\end{array}$ \\
\hline $\begin{array}{l}\text { Absorbable } \\
\text { Agents }\end{array}$ & $\begin{array}{l}\text { Oxidized } \\
\text { Regenerated } \\
\text { Cellulose }\end{array}$ & $\begin{array}{l}\text { Surgicel }{ }^{\circledR} \\
\text { Original }{ }^{\circledR} \\
\text { NuKnit }{ }^{\circledR} \\
\text { Fibrillar }^{T M}\end{array}$ & $\begin{array}{l}\text { Creates scaffold for platelet } \\
\text { aggregation, Bactericidal } \\
\text { properties. }\end{array}$ & $\begin{array}{l}\text { Infection, abscess, foreign body } \\
\text { reaction (Voormolen et al. 1987; } \\
\text { Güven, 2019). }\end{array}$ \\
\hline $\begin{array}{l}\text { Absorbable } \\
\text { Agents }\end{array}$ & $\begin{array}{l}\text { Microfibrillar } \\
\text { Collagen }\end{array}$ & $\begin{array}{l}\text { Avitene }^{\circledR} \\
\text { Ultrafoam } \\
\text { Helitene }^{\circledR}\end{array}$ & $\begin{array}{l}\text { Creates scaffold for platelet } \\
\text { aggregation. }\end{array}$ & $\begin{array}{l}\text { Granuloma formation Ereth-Market } \\
\text { al., 2008). }\end{array}$ \\
\hline $\begin{array}{l}\text { Absorbable } \\
\text { Agents }\end{array}$ & $\begin{array}{l}\text { Microporous } \\
\text { Polysaccharide }\end{array}$ & Arista ${ }^{\mathrm{TM}}$ & $\begin{array}{l}\text { Absorbs water and other low } \\
\text { molecular weight compounds from } \\
\text { the blood and concentrates these } \\
\text { components to form platelet plug. }\end{array}$ & $\begin{array}{l}\text { Expensive, no disadvantages } \\
\text { reported(Güven, 2019). }\end{array}$ \\
\hline $\begin{array}{l}\text { Absorbable } \\
\text { Agents }\end{array}$ & Gelatin & $\begin{array}{l}\text { Gelfoam }^{\circledR} \\
\text { Surgifoam }\end{array}$ & $\begin{array}{l}\text { Gelatin matrix: Absorbs surrounding } \\
\text { blood, increasing the agent's size } \\
\text { and weight. }\end{array}$ & $\begin{array}{c}\text { Infection, abscess (Lindstrom, } \\
\text { 1956). }\end{array}$ \\
\hline $\begin{array}{l}\text { Biologic } \\
\text { Agents }\end{array}$ & $\begin{array}{l}\text { Topical } \\
\text { Thrombin } \\
\text { Gelatin }\end{array}$ & Thrombi-Gel ${ }^{\circledR}$ & $\begin{array}{l}\text { Topical thrombin: Converts } \\
\text { fibrinogen to fibrin, activates } \\
\text { platelets, aiding in formation of } \\
\text { platelet plug Gelatin matrix: Absorbs } \\
\text { surrounding blood, increasing the } \\
\text { agent's size and weight. }\end{array}$ & $\begin{array}{l}\text { Intravascular implementation: } \\
\text { coagulopathies due to thrombosis, } \\
\text { expensive (Güven, 2019). }\end{array}$ \\
\hline $\begin{array}{l}\text { Biologic } \\
\text { Agents }\end{array}$ & Fibrin Sealant* & $\begin{array}{l}\text { Tisseel }{ }^{\circledR} \\
\text { TachoSil }^{\circledR} \\
\text { Evicel }^{\circledR}\end{array}$ & $\begin{array}{c}\text { Comprised of two components: } \\
\text { Sealer protein solution: Contains } \\
\text { aprotinin, factor XIII and fibrinogen } \\
\text { Thrombin solution: Converts } \\
\text { fibrinogen in protein solution to } \\
\text { fibrin. }\end{array}$ & $\begin{array}{l}\text { Risk of bloodborne virus, expensive } \\
\text { (Güven, 2019). } \\
\text { Preparation requirements make it an } \\
\text { impractical choice in the emergency } \\
\text { setting (Schreiber \& Neveleff, } \\
\text { 2011). }\end{array}$ \\
\hline $\begin{array}{l}\text { Chemical } \\
\text { Agents }\end{array}$ & $\begin{array}{l}\text { Thymus } \\
\text { vulgaris, } \\
\text { Glycyrrhiza } \\
\text { glabra, Vitis } \\
\text { vinifera, Alpinia } \\
\text { officinarum, } \\
\text { Urtica dioica } \\
\text { extract }\end{array}$ & $\begin{array}{c}\text { Ankaferd } \\
\text { Bloodstopper }^{\circledR}\end{array}$ & $\begin{array}{l}\text { Ankaferd Bloodstopper }{ }^{\circledR} \text { has } \\
\text { hemostatic effects on vascular } \\
\text { dynamics and mediators. }\end{array}$ & $\begin{array}{c}\text { Application difficulty in narrow areas } \\
\text { due to low viscosity. } \\
\text { The agent led to increased acute and } \\
\text { chronic inflammatory changes in the } \\
\text { lungs and serosal surfaces of the } \\
\text { intestines with minor architectural } \\
\text { changes in the liver (Cömert et } \\
\text { al.,2010). }\end{array}$ \\
\hline $\begin{array}{l}\text { Chemical } \\
\text { Agents }\end{array}$ & $\begin{array}{l}\text { Epinephrine } \\
\text { Chloride }\end{array}$ & $\begin{array}{l}\text { Adrenalin }{ }^{\circledR} \\
\text { Auvi- } Q^{\circledR} \\
\text { Epipen }{ }^{\circledR} \\
\text { Epipen } \mathrm{Jr}^{\circledR}\end{array}$ & $\begin{array}{l}\text { Epinephrine chloride works as a } \\
\text { vasoconstrictor and reduces the } \\
\text { amount of blood that accumulates } \\
\text { in the wound area by narrowing the } \\
\text { capillaries. }\end{array}$ & $\begin{array}{l}\text { Vasoconstriction occurs with the use } \\
\text { of adrenaline, but then vasodilation } \\
\text { is seen (Tanaka, Key \& Levy, 2009). }\end{array}$ \\
\hline $\begin{array}{l}\text { Chemical } \\
\text { Agents }\end{array}$ & Tranexamic acid & Transamine ${ }^{\circledR}$ & $\begin{array}{l}\text { The binding of plasminogen to } \\
\text { fibrin is blocked, activation of } \\
\text { plasminogen is also prevented. }\end{array}$ & $\begin{array}{l}\text { When taken in the first three hours, } \\
\text { it was found to have a tremendous } \\
\text { effect (Napolitano, Cohen, Cotton, } \\
\text { Schreiber \& Moore, 2013). }\end{array}$ \\
\hline $\begin{array}{l}\text { Chemical } \\
\text { Agents }\end{array}$ & Vitamin $\mathrm{K}$ & Konakion ${ }^{\circledR}$ & $\begin{array}{l}\text { Adequate amounts of Vitamin Kare } \\
\text { used in the prevention of clotting } \\
\text { problems in newborns and in the } \\
\text { treatment of bleeding induced by } \\
\text { medicines. }\end{array}$ & $\begin{array}{l}\text { It can be used to reverse the effect of } \\
\text { warfarin used in excessive amounts } \\
\text { to prevent blood clotting. Taking } \\
\text { vitamin K1 orally or by injection may } \\
\text { counteract anticoagulation caused } \\
\text { by warfarin. However, it is thought } \\
\text { that injecting vitamin K1 under the } \\
\text { skin is not effective (Pathak et. } \\
\text { al.Hamm, Eyal, Walter, Rijhsinghanie } \\
\text { \& Bohlman,1990). }\end{array}$ \\
\hline $\begin{array}{l}\text { Chemical } \\
\text { Agents }\end{array}$ & Protamine & $\begin{array}{l}\text { Promin }^{\circledR} \\
\text { Pamintu }^{\circledR}\end{array}$ & $\begin{array}{l}\text { Protamine is used in cardiacsurgery, } \\
\text { vascular surgeries and } \\
\text { interventional radiology procedures } \\
\text { to neutralize the anticoagulant } \\
\text { effects of heparin. }\end{array}$ & $\begin{array}{l}\text { Side effects include increased } \\
\text { pulmonary artery pressure } \\
\text { and peripheral blood pressure, } \\
\text { decreased myocardial oxygen } \\
\text { consumption, decreased heart } \\
\text { output and heart rate } \\
\text { (Carr \& Silverman, 1999). }\end{array}$ \\
\hline
\end{tabular}


Table 1. Continued.

\begin{tabular}{|c|c|c|c|c|}
\hline Type & Content & $\begin{array}{c}\text { Brand } \\
\text { Name(s) }\end{array}$ & Mechanism of Action & $\begin{array}{l}\text { Studies and Disadvantages: } \\
\text { Drawbacks of Materials }\end{array}$ \\
\hline $\begin{array}{l}\text { Chemical } \\
\text { Agents }\end{array}$ & $\begin{array}{l}\text { Aminocaproic } \\
\text { Acid }\end{array}$ & Amicar $^{\circledR}$ & $\begin{array}{l}\text { It has also been approved by the } \\
\text { FDA to prevent recurrent bleeding in } \\
\text { patients with traumatic hyphema. }\end{array}$ & $\begin{array}{l}\text { Control of perioperative bleeding } \\
\text { associated with cardiac surgery is also } \\
\text { used to prevent excessive bleeding in } \\
\text { patients under anticoagulation therapy } \\
\text { and to reduce the risk of bleeding in } \\
\text { acute promyelocytic leukemia patients } \\
\text { (Lu et al., 2015). }\end{array}$ \\
\hline $\begin{array}{l}\text { Chemical } \\
\text { Agents }\end{array}$ & $\begin{array}{l}\text { Granular clay } \\
\text { made out of } \\
\text { smectite }\end{array}$ & WoundStat ${ }^{\circledR}$ & $\begin{array}{l}\text { It swells and thus can conform to any } \\
\text { wound. }\end{array}$ & $\begin{array}{l}\text { Removing can be difficult and } \\
\text { requires debridement (Schreiber et } \\
\text { al., 2011). }\end{array}$ \\
\hline $\begin{array}{l}\text { Chemical } \\
\text { Agents }\end{array}$ & $\begin{array}{l}\text { Granular } \\
\text { zeolite and } \\
\quad \text { kaolin }\end{array}$ & $\begin{array}{l}\text { QuikClot } \\
\text { Combat } \\
\text { Gauze }^{\circledR}\end{array}$ & $\begin{array}{l}\text { QuikClot works by absorbing water } \\
\text { and concentrating coagulation } \\
\text { factors. }\end{array}$ & $\begin{array}{l}\text { It should not be touched by the } \\
\text { clinician without the use of gloves. } \\
\text { This substance has the potential to } \\
\text { produce burns (Schreiber et al., 2011). }\end{array}$ \\
\hline $\begin{array}{l}\text { Chemical } \\
\text { Agents }\end{array}$ & Chitosan & $\mathrm{HemCon}^{\circledR}$ & $\begin{array}{c}\text { Chitosan has mucoadhesive } \\
\text { properties that } \\
\text { enable the HemCon bandage to stick } \\
\text { to the wound. }\end{array}$ & $\begin{array}{c}\text { These dressings are stiff and } \\
\text { nonconformable and thus can be } \\
\text { difficult to apply (Wedmore, McManus, } \\
\text { Pusateri \& Holcomb, 2006). }\end{array}$ \\
\hline
\end{tabular}

\section{Determination of viscosity}

The viscosity of the in-situ gel formulations was performed with a vibro viscometer (AND, SV-10, Japan). The formulations were performed with $50 \mathrm{~Hz}$ at $32 \pm 2^{\circ} \mathrm{C}$.

\section{Spreadability studies of formulation}

The spreadability of the gel was measured by spreading of 0.5 $\mathrm{g}$ of the gel on a circle of $2 \mathrm{~cm}$ diameter premarked on a glass plate and then a second glass plate was employed. Half kilogram of weight was permitted to rest on the upper glass plate for $5 \mathrm{~min}$. The diameter of the circle after spreading of the gel was determined (Shinde, Pokharkar, \& Modani, 2012).

\section{Screening antimicrobial activity}

All test microorganisms, including Klebsiella pneumoniae, Acinetobacter baumannii, Staphylococcus aureus, vancomycin-resistant enterococci (VRE)+, Escherichia coli, Candida albicans (C.P. Robin) C. tropicalis (Castell.) C. krusei (Kudryavtsev), C. guilliermondii (Kurtzman and Suzuki) and C. glabrata (H.W. Anderson) were obtained from the Duzce University Research Hospital (Duzce, Turkey). The microorganisms were stored in a refrigerator at $4^{\circ} \mathrm{C}$ prior to the study.

The disk diffusion method for antimicrobial susceptibility testing was carried out according to the Clinical and Laboratory Standards Institute (CLSI) technique to assess the antimicrobial activities of the gel formulation. The formulation was performed under sterile conditions in duplicate and repeated three times (Gedik et al., 2019).

\section{In-vivo experimental design}

Three healthy female rats were supplied by Trakya University's Experimental Research Center Animal Laboratory for bleeding and clotting time tests. The study was approved by the Animal Experiments Local Ethics Committee of Trakya University (TUHADYEK-2016/36). Experimental animals were maintained in the same room in a clean environment with adequate ventilation under the following conditions: 1 atm pressure, $25^{\circ} \mathrm{C}$ temperature, and 12-hour light-and-dark cycle. During the study, the rats were fed dry pellets and water ad libitum.

\section{Bleeding assay}

One of the rats was used as a control for determining normal bleeding and clotting time. The others were for testing 5\% F. fomentarius gel formulation effect on bleeding and clotting time. On behalf of bleeding, two wound models were created in two different area of the rat body:

\section{1) $5 \mathrm{~mm}$ diameter biopsy punch wound on nape, \\ 2) $5 \mathrm{~mm}$ diameter tail cut wound}

$5 \%$ formula dose was prepared as separated $0.1 \mathrm{~g}$ sufficient applicable packages to fully-cover wound surface areas. All surgical procedures were performed under sterile conditions. The animals were anesthetized by an intramuscular injection of ketamine hydrochloride $50 \mathrm{mg} / \mathrm{kg}$ and xylazine hydrochloride $10 \mathrm{mg} / \mathrm{kg}$. All test procedures were performed according to Duke's Method and Slide Method (Nilsson, Magnusson \& Borchgrevink 1963; Waghmare \& Muniyappanavar, 2018).

Before creating a skin wound on the nape, the neck hair was shaved then cleaned with 70\% alcohol. A 5 mm diameter skin was incised using a biopsy punch with a $2 \mathrm{~mm}$ depth. Bleeding time was counted with a stopwatch (refers to incision to end of bleeding). Three drops of blood were carried on a glass plate to observe the clotting time with another stopwatch simultaneously.

A $5 \mathrm{~mm}$ diameter tail cut wound was created using a scalpel after the skin test. The cut tail was left on the ground at the same level as the heart. The same measurement procedures for bleeding and clotting time were conducted. All wounds 
were sutured and cleaned with iodized antiseptic after the procedure was completed. The rats were placed in their cages and allowed to wake up.

\section{Statistical analysis}

Statistical analyses were conducted using SPSS, version 20.0 (SPSS, Inc., Chicago, IL). The mean and standard deviation were calculated for each group. All data were expressed as means and $95 \%$ confidence intervals $(\mathrm{Cls}) \mathrm{p}<0.05$ was considered statistically significant.

\section{RESULTS}

Preparation and characterization of gel formulations

The physicochemical characterization parameters of gels are reported in Table 2 . The clarity, viscosity and spreadability of all the formulations were found to be satisfactory. The $\mathrm{pH}$ of the developed gel ranged between 5.49 and 5.55. The $\mathrm{pH}$ of the gels was appropriate for the dermal application. The spreadability of the gel was considered high by having, only two seconds. The therapeutic efficacy of gels depends on their spread.

Table 2. Clarity, pH, viscosity, spreadability of gel formulation.

\begin{tabular}{|ll|}
\hline Clarity & ++ \\
$\mathrm{pH}$ & $5.52 \pm 0.01$ \\
Viscosity $(\mathrm{P})$ & $34.1 \mathrm{P} \pm 0.22\left(29,4^{\circ} \mathrm{C}\right)$ \\
Spreadability $(\mathrm{cm})$ & $1.72 \pm 0.17(\leq 2$ seconds $)$ \\
\hline The data are presented as the mean \pm standard deviation (SD).
\end{tabular}

\section{Screening antimicrobial activity}

The antimicrobial activity of gel formulation was performed against Klebsiella pneumoniae, Acinetobacter baumannii, Staphylococcus aureus, vancomycin-resistant enterococci (VRE)+,
Escherichia coli, Candida albicans, C. tropicalis, C. krusei, C. guilliermondii and C. glabrata. The antimicrobial results of formulations are reported in Table 3. Agar well diffusion test results revealed that gel formulation showed a good inhibition zone with the strongest value against Klebsiella pneumoniae (10.3 $\pm 0.79 \mathrm{~mm})$, Candida krusei $(11 \pm 0.26 \mathrm{~mm})$, C. tropicalis $(9 \pm 0.17 \mathrm{~mm})$, C. guilliermondii (10.2 $\pm 0.4 \mathrm{~mm}$ ) (Gedik et al., 2019)

\section{Bleeding assay}

$5 \mathrm{~mm}$ diameter biopsy punch wound on nape:

Results obtained from the experiments were summarized in the Table 4. After confirming continuous bleeding from the full-thickness skin wound, the application of the gel resulted in rapid hemostasis. The gel administration shortened the hemostasis time after bleeding from the skin incisions by 3:32:57 minutes or $63.9 \%$ from the original time of 9:48:39. For coagulation time these results are determined as follows: 2:31:20 minutes or $71.56 \%$ from the original time of 8:51:50.

\section{Table 4. Bleeding Assay with Biopsy Punch Wound on Nape.}

\begin{tabular}{|cccc|}
\hline \multicolumn{2}{|c}{ Control } & \multicolumn{2}{c|}{ Gel Application } \\
\hline $\begin{array}{c}\text { Bleeding } \\
\text { Time }\end{array}$ & $\begin{array}{c}\text { Coagulation } \\
\text { Time }\end{array}$ & $\begin{array}{c}\text { Bleeding } \\
\text { Time }\end{array}$ & $\begin{array}{c}\text { Coagulation } \\
\text { Time }\end{array}$ \\
\hline $9: 48: 39$ & $8: 51: 50 \pm 0.07$ & $3: 32: 57 \pm 0.09$ & $2: 31: 20 \pm 0.06$ \\
$(588 s n)(n=1)$ & $(531 \mathrm{sn})(n=3)$ & $(212 s n)(n=2)$ & $(151 s n)(n=6)$ \\
\hline$(p=0.002)$ & & & \\
\hline
\end{tabular}

$5 \mathrm{~mm}$ diameter tail cut wound:

Results obtained from the experiments were summarized in the Table 5. After confirming continuous bleeding from the tail wound, the application of the gel resulted in rapid hemostasis. The gel administration shortened the hemostasis time after bleeding from the tail incisions by 5:27:05 minutes or 55.63\%

Table 3. Antibacterial and antifungal activity of gel formulation.

\begin{tabular}{|c|c|c|c|c|c|c|c|}
\hline \multirow{2}{*}{ Test Microorganisms } & \multicolumn{7}{|c|}{ Inhibition zones $(\mathrm{mm})$ * } \\
\hline & Gel Formulation & $E$ & GN & AM & AMB & FLU & KTC \\
\hline Klebsiella pneumoniae & $10.3 \pm 0.79$ & NT & - & 7 & NT & NT & NT \\
\hline Acinetobacter baumannii & - & NT & 9 & 10 & NT & NT & NT \\
\hline Staphylococcus aureus & $10.5 \pm 0.43$ & 14 & NT & 11 & NT & NT & NT \\
\hline **VRE+ & - & 10 & 12 & 9 & NT & NT & NT \\
\hline Escherichia coli & $7.0 \pm 0.01$ & 11 & NT & - & NT & NT & NT \\
\hline Candida krusei & $11 \pm 0.26$ & NT & NT & NT & 9 & - & - \\
\hline C. albicans & $7 \pm 0.45$ & NT & NT & NT & 9 & 8 & 9 \\
\hline C. tropicalis & $9 \pm 0.17$ & NT & NT & NT & - & - & - \\
\hline C. guilliermondii & $10.2 \pm 0.4$ & NT & NT & NT & 8 & - & - \\
\hline C. glabrata & $10 \pm 0.62$ & NT & NT & NT & - & - & 15 \\
\hline
\end{tabular}


from the original time of 12:17:06. For coagulation time these results are determined as follows: 2:01:69 minutes or 69.9\% from the original time of 6:42:48.

Table 5. Bleeding Assay with Tail Cut Wound.

\begin{tabular}{|cccc|}
\hline \multicolumn{2}{|c|}{ Control } & \multicolumn{2}{c|}{ Gel Application } \\
\hline $\begin{array}{c}\text { Bleeding } \\
\text { Time }\end{array}$ & $\begin{array}{c}\text { Coagulation } \\
\text { Time }\end{array}$ & $\begin{array}{c}\text { Bleeding } \\
\text { Time }\end{array}$ & $\begin{array}{c}\text { Coagulation } \\
\text { Time }\end{array}$ \\
\hline $12: 17: 06$ & $6: 42: 48 \pm 0.11$ & $5: 27: 05 \pm 0.07$ & $2: 01: 69 \pm 0.02$ \\
$(737 s n)(n=1)$ & $(402 s n)(n=3)$ & $(327 s n)(n=2)$ & $(121 s n)(n=6)$ \\
\hline$(p=0.006)$ & & & \\
\hline
\end{tabular}

\section{DISCUSSION}

This study evaluated the hemostatic effects of $5 \%$ F. fomentarius gel formulation in vivo in rat skin-tail bleeding models. Today, in addition to conventional anti-bleeding methods, the use of extracts from various plants and marine organisms has become popular. The aim of this study was to investigate the effect of the F. fomentarius which is a common fungal species on bleeding time and clotting time. Gel formulation provides better application property and stability in comparison to cream and ointment. Topical gel drug administration is a localized drug delivery system anywhere in the body (Kaur \& Guleri, 2013). The gel was made for this purpose and cross-linked polymer of acrylic acid was used as a gelling agent. Carbomer 940 polymer is a white powder, crosslinked polyacrylic acid polymer. Its short flow, nondrip properties are ideal for applications such as clear gels, hydroalcoholic gels, and creams. This gels are optimum viscosity at $25^{\circ} \mathrm{C}$ and physiological temperature, making them optimum gelling agent for dermal applications (https:// www.lubrizol.com/en/Personal-Care/Products/ProductFinder/Products-Data/Carbopol-940-polymer).

The gel formulation characterized based on its $\mathrm{pH}$, clarity, and viscosity. Physicochemical characterization of in situ gel formulations is an important subject to be considered in the formulation part, especially those intended for dermal application. The gel has a clear appearance on visual inspection. The $\mathrm{pH}$ of the developed gel ranged between 5.49 and 5.55. Ideally, dermal formulations should possess $\mathrm{pH}$ in the range of $5-6$, for minimizing the discomfort of patient or skin irritation due to acidic $\mathrm{pH}$ and microbial growth on the skin because of basic pH (Okur, Çağlar, \& Arpa, 2017). The outcomes of the characterization analysis indicate the development of successful gel formulation with optimum characteristics.

The spreadability of the gel was considered high by having a low spread of time. The gel spreading helps in the uniform application of the gel to the skin, so the prepared gels must have a good spreadability and satisfy the ideal quality in topical application. Furthermore, this is considered an important factor in patient compliance with treatment. This gels viscosity properties with possible pseudoplastic behavior observed in the formulation, confirms the characteristic of high spreadability due to the decrease in viscosity when applying certain force, and at the same time has the property of remaining at the application site without drain (Carvalho et al., 2010).

Data from the antimicrobial study showed a good inhibition zone with the strongest value against Klebsiella pneumoniae, Candida krusei, C. tropicalis, C. guilliermondii. Similar to the our study, Kolundžić et al. (2016) tested the antimicrobial activity of F. fomentarius extracts of different polarity, especially against Gram-negative and Gram-positive bacteria that are commonly related to dermal and hospital infections (Staphylococcus aureus Rosenbach, S. epidermidis (Winslow and Winslow), Micrococcus luteus (Schroeter), Bacillus subtilis (Ehrenberg), Enterococcus faecalis (Andrewes and Horder), Escherichia coli (Migula) Castellani and Chalmers, Klebsiella pneumoniae (Schroeter) Trevisan and Pseudomonas aeruginosa (Schröter). They indicated that their F. fomentarius extracts (C-cyclohexane, D-dichloromethane, M-methanol and A-aqueous) displayed strong antimicrobial activity. Hereby, it can be concluded that the antimicrobial efficiency of the fungi gel formulation could provide a convenient surrounding for hemostatic efficacy by preventing wound infections caused by bleeding.

Pyranose is a collective term for saccharides that have a chemical structure that includes a six-membered ring consisting of five carbon atoms and one oxygen atom. This saccharide's pKa is also 11.8 in strong acid character. These electrolyte structures are biological environments force them to load cationic. (http://foodb.ca/compounds/FDB015634).

It has an anti-hemorrhagic effect by positively charged polysaccharide and polysaccharide-protein complex structure by binding chemical and mechanical effects with negatively charged erythrocytes, activating platelets and forming an adhesive structure in the tissue and forming a physical barrier around the injured vessel.

In our study, the gel administration shortened the hemostasis time after bleeding from the skin incisions by $63.9 \%$ and the tail incisions by $55.63 \%$ from the original time. For coagulation time these results are determined as follows $71.56 \%$ from the original time in skin incisions model and 69.9\% from the original time in the tail incisions model.

\section{CONCLUSION}

Our preliminary study showed that the gel formulation obtained from F. fomentarius is a potent hemostatic agent for cutaneous bleeding resulting from surgical skin defects in a rat-bleeding model. The use of the gel in especially in patients with hemostatic abnormalities, those undergoing anticoagulant or antiaggregant therapy, pregnant patients, or people with cancer may be an alternative to other hemostatic agents for achieving effective bleeding control. Future controlled clinical trials are needed to evaluate the efficacy of the plant extract in the control of hemorrhaging during surgery.

In particular, the search for hemostatic agent of natural origin is progressing rapidly, which points to the need for further studies exploring the utilization of the therapeutic agents from F. fomentarius. 
Ethics Committee Approval: The study were approved by animal experiments local ethics committee of Trakya University (TUHADYEK-2016/36) and indicated in the method section.

Peer-review: Externally peer-reviewed.

Author Contributions: Conception/Design of Study- G.G., A.Ö., H.A.; Data Acquisition- G.G., A.Ö.; Data Analysis/Interpretation- G.G., H.N., Ö.S.; Drafting Manuscript- G.G., A.Ö., H.A., H.A., A.A.; Critical Revision of Manuscript- A.A., G.G.; Final Approval and Accountability- G.G., H.A., A.Ö., H.A., A.A., H.N., Ö.S.; Technical or Material Support- H.A., G.G.; Supervision- A.A., G.G.

Conflict of Interest: The authors have no conflict of interest to declare.

Financial Disclosure: Authors declared no financial support.

\section{REFERENCES}

- Akramiene, D., Kondrotas, A., Didziapetriene, J. \& Kevelaitis, E. (2007). Effects of beta-glucans on the immune system. Medicina, 43(8), 597-606. https://doi.org/10.3390/medicina43080076

- Allı, H., Işıloğlu, M. \& Solak, M. H. (2007). Macrofungi of Aydın Province. Mycotaxon, 99(1), 163-165. Retrieved from https://www.researchgate.net/publication/282726082_Macrofungi_of_Aydin_ Province_Turkey_65/link/5c8966b5a6fdcc3817526251.

- Carr, J. A., Silverman, N. (1999). The heparin-protamine interaction: A review. The Journal of Cardiovascular Surgery, 40(5), 659-666. Retrieved from https://europepmc.org/article/med/10596998.

- Carvalho, F. C., Barb, M. S., Sarmento, V. H. V., Chiavacci, L. A., Netto, F. M. \& Gremiao, M. P. D. (2010). Surfactant systems for nasal zidovudine delivery structural, rheological and mucoadhesive properties. Journal of Pharmacy Pharmacology, 62(4), 430-439. https:// doi.org/10.1211/jpp.62.04.0004.

- Chen, W, Zhao Z, Li Y. (2011). Simultaneous increase of mycelial biomass and intracellular polysaccharide from Fomes fomentarius and its biological function of gastric cancer intervention. Carbohydrate Polymers, 85(2), 369-375. https://doi.org/10.1016/j.carbpol.2011.02.035.

- Cömert, M., Karakaya, K, Barut, F., Çakmak, K. G., Uçan, H. B., Gültekin, F. A., Emre, A. U., Taşçılar, Ö., Irkörücü, O., Ankaralı, H. (2010). Does intraabdominal use of Ankaferd Blood Stopper cause increased intraperitoneal adhesions. National Trauma and Emergency of Surgery Journal, 16(5), 383-389. Retrieved from https:// pubmed.ncbi.nlm.nih.gov/21038113.

- Dresch, P., D’Aguanno, M. N., Rosam, K., Grienke, U., Rollinger, J. M., Ursula Peintner, U. (2015). Fungal strain matters: colony growth and bioactivity of the European medicinal polypores Fomes fomentarius, Fomitopsis pinicola and Piptoporus betulinus. AMB Express, 5(4). https://doi.org/10.1186/s13568-014-0093-0.

- Ellis, M. B. \& Ellis, J. P. (1990). Fungi without gills (Hymenomycetes and Gasteromycetes). An Identification Handbook. XI, 329 S., 543 Abb. Chapman and Hall, London, New York, Tokyo, Melbourne, Madras, 1990. ISBN 0-412-36970-2

- $\quad$ Ereth-Mark, H., Schaft, M., Ericson, E., Wetgen, N., Nuttal, G., Oliver, W. C. (2008). Comparative safety and efficacy of topical hemostatic agents in a rat neurosurgical model. Neurosurgery, 63, 369-372. https://doi.org/10.1227/01.neu.0000327031.98098.dd.

- Gedik, G., Dülger, G., Asan, H., Özyurt, A., All, H. \& Asan A. (2019). The antimicrobial effect of various formulations obtained from Fomes fomentarius against hospital isolates. Mantar Dergisi- The Journal of Fungus, 10(2), 103-109. https://doi.org/ 10.30708/mantar.535994.
Grienke, U., Zöll, M., Peintner, U. \& Rollinger, J. M. (2014). European medicinal polypores-A modern view on traditional uses. Journal of Ethnopharmacology, 154(3), 564-583. https://doi.org/10.1016/j. jep.2014.04.030.

- Güven, R. (2019). An experimental study investigating the effect of local hemostatic agents on hemostatic, histopathological, antimullerian hormone and postoperative intraabdominal adhesion in a laceration model of complicated ovarian hyperstimulation (Expertise thesis in medicine). Available from tez.yok.gov.tr. (No. 535721).

- Kaur, L. P., Guleri, T. K. (2013). Topical Gel: A Recent Approach for Novel Drug delivery. Asian Journal of Biomedical and Pharmaceutical Sciences, 3(17), 1-5. https://doi.org/10.15272/AJBPS.V3|17.183. Kheirabadi, B. S. (2011). Evaluation of topical hemostatic agents for combat wound treatment. The United States Army Medical Department Journal, 2, 25-38. Retrieved from https://pubmed.ncbi. nlm.nih.gov/21607904.

- Kolundžić, M., Grozdanić, N. D., Dodevska, M., Milenković, M., Sisto, F., Miani, A. \& Kundaković, T. (2016). Antibacterial and cytotoxic activities of wild mushroom Fomes fomentarius (L.) Fr. Polyporaceae. Industrial Crops and Products, 79, 110-115. https://doi. org/10.1016/j.indcrop.2015.10.030.

- Lindstrom, P. A. (1956). Complications from the use of absorbable hemostatic sponges. American Medical Association Archive of Surgery, 73(1), 133-141. https://doi.org/10.1001/archsurg.1956.01280010135018.

- $\quad$ Lu, J., Meng, H., Meng, Z., Sun, Y., Pribis, J. P., Zhu, C., Li, Q. (2015). Epsilon aminocaproic acid reduces blood transfusion and improves the coagulation test after pediatric open-heart surgery: A metaanalysis of 5 clinical trials. International Journal of Clinical and Experimental Pathology, 8(7), 7978-7987. Retrieved from https:// pubmed.ncbi.nlm.nih.gov/26339364.

Napolitano, L. M., Cohen, M. J., Cotton, B. A., Schreiber, M. A., Moore, E. E. (2013). Tranexamic acid in trauma: how should we use it ? Journal of Trauma and Acute Care Surgery, 74(6), 1575-86. https://doi.org/10.1097/ta.0b013e318292cc54.

Nilsson, I. M., Magnusson, S., Borchgrevink, C. (1963).The Duke and Ivy methods for determination of the bleeding time. Thrombosis et Diathesis Haemorrhagica 10.02: 223-234. Retrieved from https://europepmc.org/article/med/14081283

- Okur, N. Ü., Çağlar, E. Ş., Arpa, M. D. \& Karasulu, H. Y. (2017). Preparation and evaluation of novel microemulsion-based hydrogels for dermal delivery of benzocaine. Pharmaceutical Development and Technology, 22(4), 500-510. https://doi.org/10.3109/10837450.2015.1131716.

- $\quad$ Okur, N. Ü., Yoltaş, A. \& Yozgatli, V. (2016). Development and characterization of voriconazole loaded in situ gel formulations for ophthalmic application. Turkish Journal of Pharmaceutical Sciences, 13(3): 311-317. https://doi.org/10.4274/tjps.2016.05

Pacioni, G. (1985). Mac Ency Mushrooms Toadstools (Macdonald encyclopedias). London.

- Park, Y. M., Kim, I. T., Park, H. J., Choi, J. W., Park, K. Y., Lee, J. D., Nam, B. H., Kim, D. G., Lee, J. Y. \& Lee, K. T. (2004). Anti-inflammatory and anti-nociceptive effects of the methanol extract of Fomes fomentarius. Biological \& Pharmaceutical Bulletin, 27(10), 1588-1593. https://doi.org/10.1248/bpb.27.1588.

Pathak, A., Hamm, C. R., Eyal, F. G., Walter, K., Rijhsinghani, A., Bohlman, M. (1990). Maternal Vitamin K administration for prevention of intraventricular hemorrhage in preterm infants. Pediatric Research, 27, 219. Retrieved from https://www.ncbi.nlm.nih.gov/ pmc/articles/PMC7043360.

Pusateri, A. E., McCarthy, S. J., Gregory, K. W., Harris, R. A., Cardenas, L., McManus, A. T., \& Goodwin Jr, C. W. (2003). Effect of a chitosanbased hemostatic dressing on blood loss and survival in a model of severe venous hemorrhage and hepatic injury in swine. Journal of Trauma and Acute Care Surgery, 54(1), 177-182. https://doi. org/10.1097/00005373-200301000-00023. 
- Schreiber, M. A, Neveleff J. D. (2011). Achieving hemostasis with topical hemostats: Making clinically and economically appropriate decisions in the surgical and travma settings. The Association of Perioperative Registered Nurses Journal, 94(5), 1-20. https:// doi.org/10.1016/j.aorn.2011.09.018.

- Seniuk, O. F., Gorovoj, L. F., Beketova, G. V., Savichuk, N. O., Rytik, P. G., Kucherov, I. \& Prilutsky A. (2011). Anti-infective properties of the melanin-glucan complex obtained from medicinal tinder bracket mushroom, Fomes fomentarius (L.: Fr.) Fr. (Aphyllophoromycetideae). International Journal of Medicinal Mushrooms, 13(1), 7-18. https://doi.org/10.1615/intjmedmushr.v13.i1.20.

- $\quad$ Seon-OK, L., Min-Ho, L., Kyung-Ran, L., Eun-OK, L., Hyo-Jeong, L. (2019). Fomes fomentarius Ethanol Extract Exerts Inhibition of Cell Growth and Motility Induction of Apoptosis via Targeting AKT in Human Breast Cancer MDA-MB-231 Cells. International Journal of Molecular Science, 20(5), 1147. https://doi.org/10.3390/ ijms20051147.

- $\quad$ Shinde, U., Pokharkar, S. \& Modani, S. (2012). Design and evaluation of microemulsion gel system of nadifloxacin. Indian Journal of Pharmaceutical Sciences, 74(3), 237-247. https://dx.doi. org/10.4103\%2F0250-474X.106066.

- Tanaka, A. K., Key, N. S., Levy, J. H. (2009). Blood coagulation: Hemostasis and thrombin regulation. Anesthesia \& Analgesia, 108(5), 1433-1446. http://doi.org/10.1213/ane.0b013e31819bcc9c.
- Vetrovsky, T., Vorísková, J., Snajdr, J., Gabriel, J. \& Baldrian, P. (2011). Ecology of coarse wood decomposition by the saprotrophic fungus Fomes fomentarius. Biodegradation, 22(4), 709-718. https:// doi.org/10.1007/s10532-010-9390-8.

- Voormolen, J. H. C., Ringers, J., Bots, G. A. M., Van Der Heide, A., Hermans, J. (1987). Hemostatic agents: Brain tissue reaction and effectiveness. Neurosurgery, 20(5), 702-709. https://doi. org/10.1227/00006123-198705000-00005.

- Waghmare, R. V., Muniyappanavar, N. S. (2018). Influence of blood groups on bleeding and clotting time. International Physiology 6(3), 200-204. https://dx.doi.org/10.21088/ip.2347.1506.6318.6.

Wedmore, I., McManus, J. G., Pusateri, A. E., Holcomb, J. B. (2006). A special report on the chitosan-based hemostatic dressing: experience in current combat operations. Journal of Trauma, 60(3), 655-658. https://doi.org/10.1097/01.ta.0000199392.91772.44.

FOODB. (2019, November 19) Retrieved from http://foodb.ca/ compounds/FDB01563.

- $\quad$ Lubrizol. (2019, December 28) Retrieved from https://www.lubrizol.com/en/Personal-Care/Products/Product-Finder/ProductsData/Carbopol-940-polymer. 